\title{
PENCAHAYAAN KANDANG SAPI DI PETERNAKAN SAWALAKSA BUANA DESA CIMAUNG, JAWA BARAT
}

\section{Endah Setyaningsih ${ }^{1}$, Yohanes Calvinus ${ }^{2}$, Hadian Satria Utama ${ }^{3}$ dan Alfina Putri Mulyo ${ }^{4}$}

\author{
${ }^{1}$ Program Studi Teknik Elektro, Universitas Tarumanagara \\ Email: endahs@ft.untar.ac.id \\ ${ }^{2}$ Program Studi Teknik Elektro, Universitas Tarumanagara \\ Email: yohanesc@ft.untar.ac.id \\ ${ }^{3}$ Program Studi Teknik Elektro, Universitas Tarumanagara \\ Email: hadianu@ft.untar.ac.id \\ ${ }^{4}$ Program Studi Teknik Elektro, Universitas Tarumanagara \\ Email: alfina.525200010@stu.untar.ac.id
}

\begin{abstract}
Sawalaksa Buana Farm was established in 2015, in Cimaung village, West Java. The area is about 1200 m2, there are two cages in the area. The first cage was used as a feedlot with a capacity of 24 bulls. The second cage, used as a cow shed for breeding, has a capacity of 20 cows. Another area is a cattle feed warehouse and a fermentation area for making feed. Cow food is the result of processing corn stalk waste by fermentation, and the Sawalaksa Buana farm produces this food. Corn stalk waste is obtained from farmers around the farm. The lighting system in the enclosure and the surrounding environment uses LED bulbs, 28 watts of power. Installation of lights in the area around the cage without using a lamp housing, both for the inside and outside/the environment. In accordance with the shape of this LED lamp, its use is more appropriate for the inside of the room, but in this farm, besides being used for the cage area, it is also used for the outside, namely the environment and around the road. The partners' problems are lack of understanding in the selection and placement of LED lights, already using LED lights, but lack of detailed specifications, selection of shapes and lamp housings that are not appropriate for lighting around the cage and for the area around the road. The solution offered is in the form of retrofitting lights on the cowshed and its environment to optimize the use of LED lights and lamp housings. The method of implementing PKM is in the form of field surveys, analyzing and replacing lamps and lamp houses in cattle pens and their environment. The results obtained from the lighting of the cage can be optimized, namely by using the type of lamp according to its designation, the use of the lamp housing and the selection of the appropriate lamp power. Thus, the purpose of implementing this PKM can be fulfilled.
\end{abstract}

Keywords: cattle farming; retrofit; lighting; LED lights; lamp housing.

\section{ABSTRAK}

Peternakan Sawalaksa Buana berdiri tahun 2015, di desa Cimaung, Jawa Barat. Luas area sekitar 1200 m2, terdapat dua kandang di area tersebut. Kandang pertama dipakai sebagai kandang penggemukan berkasipasitas 24 ekor sapi jantan. Kandang kedua, dimanfaatkan sebagai kandang sapi betina untuk pembibitan/breeding, berkapasitas 20 ekor sapi betina. Area lain berupa gudang makanan sapi dan area fermentasi pembuatan pakan. Makanan sapi berupa hasil pengolahan limbah batang jagung dengan cara difermentasi, dan makanan ini diproduksi sendiri oleh peternakan Sawalaksa Buana. Limbah batang jagung diperoleh dari petani sekitar peternakan. Sistem pencahayaan pada kandang dan lingkungan sekitarnya menggunakan lampu bohlam LED, daya 28 watt. Pemasangan lampu pada area sekitar kandang tanpa menggunakan rumah lampu, baik untuk bagian dalam dan luar/lingkungan. Sesuai dengan bentuk lampu LED ini, penggunaannya lebih tepat untuk ruangan bagian dalam, namun di peternakan ini, selain digunakan untuk area kandang, juga untuk bagian luar yaitu lingkungan dan sekitar jalan. Permasalahan mitra adalah kurang paham dalam pemilihan dan penempatan lampu LED, sudah menggunakan lampu LED, namun spesifikasi kurang detil, pemilihan bentuk dan rumah lampu yang kurang tepat untuk pencahayaaan sekitar kandang dan untuk area sekitar jalan. Solusi yang ditawarkan berupa retrofit lampu pada kandang sapi dan lingkungannya untuk mengoptimalkan penggunaan lampu LED dan rumah lampu. Metode pelaksanaan PKM berupa survei lapangan, menganalisis dan penggantian lampu dan rumah lampu pada kandang sapi dan lingkungannya. Hasil yang diperoleh pencahayaan kandang dapat dioptimalkan, yaitu dengan penggunaan jenis lampu sesuai peruntukannya, penggunaan rumah lampu dan pemilihan daya lampu yang sesuai. Dengan demikian tujuan pelaksanaan PKM ini dapat terpenuhi. Kata Kunci: peternakan sapi; retrofit; pencahayaan; lampu LED; rumah lampu. 


\section{PENDAHULUAN}

Peternakan Sawalaksa Buana didirikan tahun 2015, di desa Ciririp, Pasir Huni, Kecamatan Cimaung, Kabupaten Bandung, Provinsi Jawa Barat. Luas area peternakan sekitar $1200 \mathrm{~m}^{2}$, terdapat dua kandang di area tersebut. Terdapat juga pojok tanaman sayuran secara hydroponik, untuk menambah konsumsi harian karyawan. Kandang pertama berkasipasitas 24 ekor sapi jantan, dengan ukuran $(17 \times 7,5 \times 2,75) \mathrm{m}$, yang dipakai sebagai kandang penggemukan disebut sebagai kandang penggemukan, (lihat Gambar 1 sebelah kiri). Sesuai gambar 1, terlihat kandang, gudang makanan dan area fermentasi pembuatan pakan. Kandang kedua, ukuran (25 x 10 x 3) m yang dimanfaatkan nantinya sebagai kandang sapi betina untuk pembibitan, disebut sebagai kandang pembibitan/breeding. Kandang sapi pembibitan berada di depan kandang penggemukan, yang direncanakan untuk sekitar 20 sapi betina.

Makanan sapi berupa hasil pengolahan limbah batang jagung dengan cara difermentasi, dan makanan ini diproduksi sendiri oleh peternakan Sawalaksa Buana. Limbah batang jagung diperoleh dari petani sekitar peternakan. Para petani ini seringkali mengambil kotoran sapi dari peternakan Sawalaksa Buana, yang digunakan sebagai pupuk alami, baik untuk tanaman jagung atau tanaman padi.

Kotoran sapi dalam satu sisi dapat digunakan sebagai bahan pupuk, namun disisi lain jika kotoran sapi ini tidak dikelola dengan baik, maka akan menimbulkan kerumunan lalat, yang dapat membawa penyakit dan berdampak bagi kesehatan karyawan. Peternak sapi, baik untuk sapi potong dan sapi perah harus memperhatikan sanitasi kandang, yang berguna untuk kesehatan karyawan. Menurut (Zuroida \& Azizah, 2018), bahwa kondisi sanitasi kandang sapi perah termasuk kategori cukup (70\%), sedangkan tingkat kepadatan lalat yang ada disekitar kandang termasuk dalam kategori sedang (48,3\%). Menurut penelitian ini tidak terdapat hubungan antara sanitasi kandang dan keluhan kesehatan yang dirasakan bagi peternak selama bekerja dikandang. Meskipun begitu peternak sapi harus tetap menjaga sanitasi kandang dengan lebih baik. Hal ini disampaikan oleh Zuroida \& Azizah (2018) dalam penelitiannya tentang sanitasi kandang peternak sapi perah di kota Jombang dengan sampel penelitian sebanyak 58 peternak. Tentang sanitasi kandang ini menjadi hal menarik untuk kegiatan PKM selanjutnya.

Selain sanitasi kandang yang baik, keamanan dan kenyamanan dilingkungan kerja peternakan sapi bagi karyawan juga perlu diperhatikan. Keamanan dalam hal ini adalah hubungannya dalam resiko kerja yang dihadapi karyawan, seperti tertularnya penyakit dan terjadinya cedera yang disebabkan oleh ulah sapi. Menurut (Pranamyaditia, 2016), menyebutkan bahwa 3 risiko tinggi yang dihadapi karyawan yaitu pencemaran, tertendang pada pekerjaan membersihkan dan tertendang pada pekerjaan maintenance. Hal ini disebutkan dalam penelitiannya terhadap peternakan sapi di PT X, cabang kota Kediri, yang dikatakan bahwa pengendalian resikonya termasuk dalam kategori kurang di beberapa aspek. Aspek tersebut yaitu perhatian terhadap kualitas alat pelindung diri, kelengkapan alat pelindung diri pekerja, dan pengendalian limbah kotoran sapi.

Sementara itu yang ada hubungannya dengan kenyamanan salah satunya yaitu adanya pencahayaan dan sirkulasi udara yang baik. Sehubungan bentuk kandang yang terbuka , maka sirkulasi udara di peternakan ini, relatif baik. Pencahayaan untuk peternakan pada siang hari sebaiknya menggunakan cahaya dari matahari, selain bebas biaya, cahaya matahari pagi juga baik bagi kesehatan sapi dan karyawannya yaitu adanya vitamin D. Pencahayaan malam hari diperlukan bantuan dari lampu listrik. Namun penting diperhatikan bahwa perlu dilakukan penggunaan lampu yang hemat energi, mengingat kebutuhan lampu listrik akan cukup banyak untuk area peternakan yang luas. Sebaiknya digunakan lampu LED yang hemat energi dibandingkan dengan lampu 
konvensional, seperti lampu pijar atau lampu fluorescent (contoh lampu TL-T8 dan lampu PL). Menurut penelitian (Candra et al, 2018), menyebutkan bahwa konsumsi daya listrik lampu TLLED lebih kecil 33,3\% dari pada lampu TL-T8. Penghematan biaya dari penggunaan lampu TLLED sebesar 33,3\% dibandingkan dengan lampu TL-T8, yaitu sebesar Rp 204.300 sampai dengan Rp. 413.100, untuk setiap komsumsi daya sebesar $100 \mathrm{kWh}$.

\section{Gambar 1}

Area Peternakan Sapi Sawalaksa Buana dan Pencahayaan Kandangnya
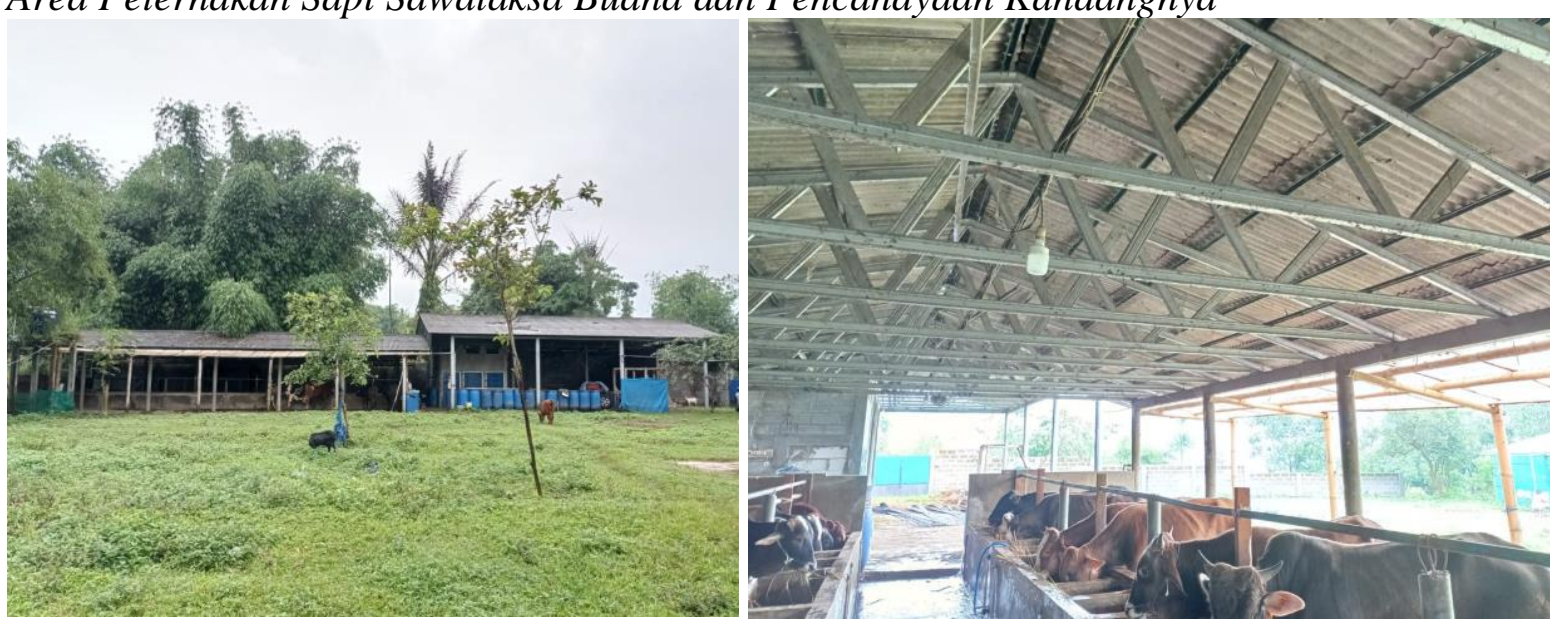

Sistem pencahayaan pada kandang dan lingkungan sekitarnya menggunakan lampu bohlam LED, dengan bentuk seperti kotak (lihat Gambar 2), dengan daya 28 watt. Lampu ini dilengkapi dengan batere built in, yang berfungsi menyimpan daya, daya ini digunakan pada saat aliran listrik PLN mati, agar lampu tetap menyala selama 4 jam. Spesifikasi lampu LED yang terdapat pada boks lampu, kurang detil, karena tidak ada nilai fluks cahaya (satuan lumen) untuk lampu tersebut sehingga tidak dapat diketahui efikasi lampunya (satuan lumen/watt). Umur lampu 8.000 jam, disebutkan setara dengan 8 x lampu pijar, namun disisi lain dalam boks, disebutkan umur lampu 40.000 jam, data ini sangat membingungkan. Tampak pada Gambar 3, pemasangan lampu pada area sekitar kandang, yang pemasangannya tanpa menggunakan rumah lampu. Sesuai dengan bentuk lampu LED ini, penggunaannya adalah untuk ruangan bagian dalam, namun di peternakan ini banyak lampu digunakan untuk lingkungan sekitar dan juga untuk penerangan jalan (Gambar 4). Terdapat 3 lampu bohlam LED dengan daya 28 watt/lampu pada kandang penggemukan, yang luasnya $120 \mathrm{~m} 2$. Sedangkan pada gudang dan area pembuatan pakan, terdapat 2 lampu LED.

Rekomendasi nilai tingkat pencahayaan untuk area peternakan sapi tidak ditemukan dalam standar nasional Indonesia (SNI). Untuk itu, dilakukan penyetaraan/asumsi, yaitu berdasarkan SNI No 6197:2020, tentang Konservasi energi pada sistem pencahayaan. Dalam hal ini disetarakan dengan bangunan industri, dengan kategori pekerjaan kasar, dibutuhkan nilai tingkat pencahayaan sebesar 200 lux. 


\section{Gambar 2}

Bentuk Lampu LED Bohlam Sesuai Gambar, Spesifikasinya dalam Boks dan Bentuk Lampu untuk Jalan Sekitar
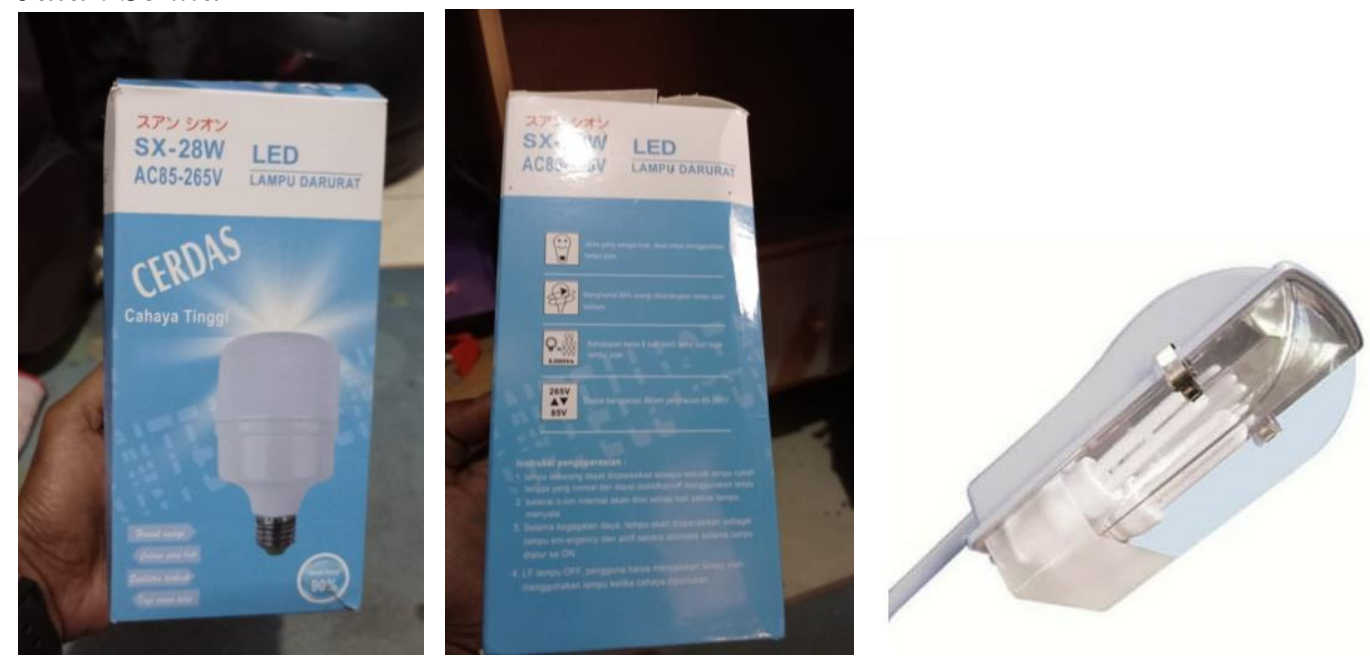

\section{Gambar 3}

Penggunaan Lampu LED di Saung, Lingkungan dan Area Pembuatan Pakan
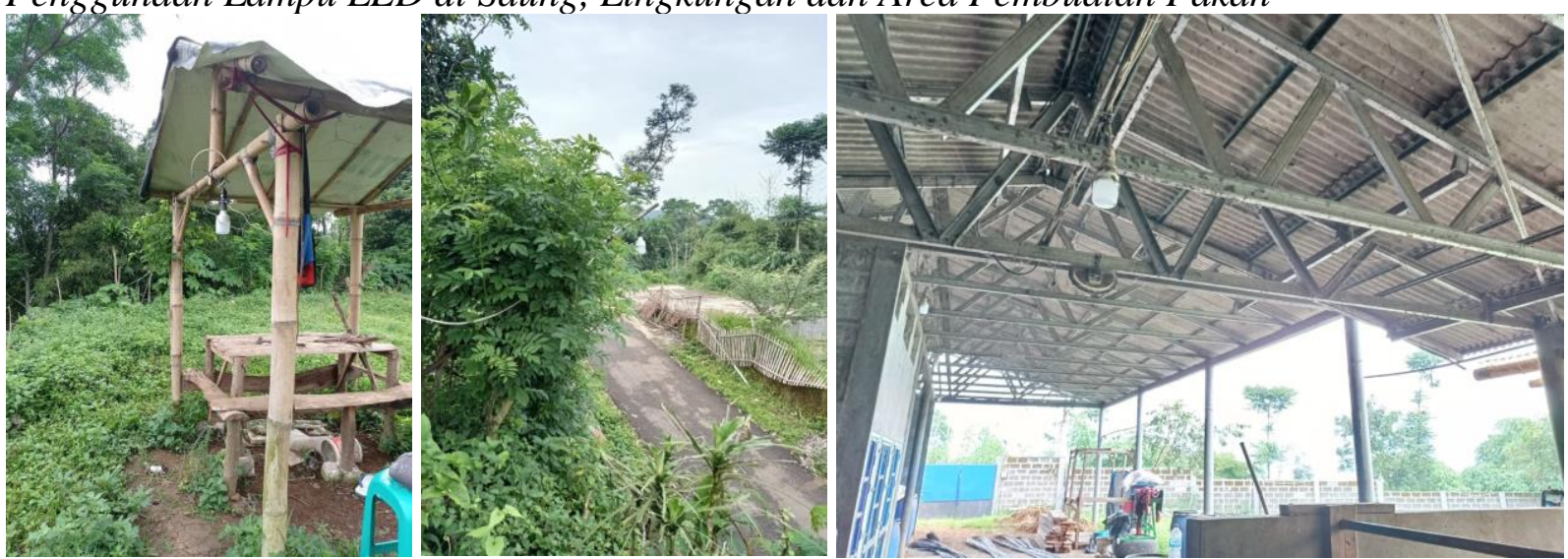

\section{Gambar 4}

Penggunaan Lampu LED di Gerbang Kandang, Sekaligus Sebagai Pencahayaan Sekitar Jalan Lingkungan
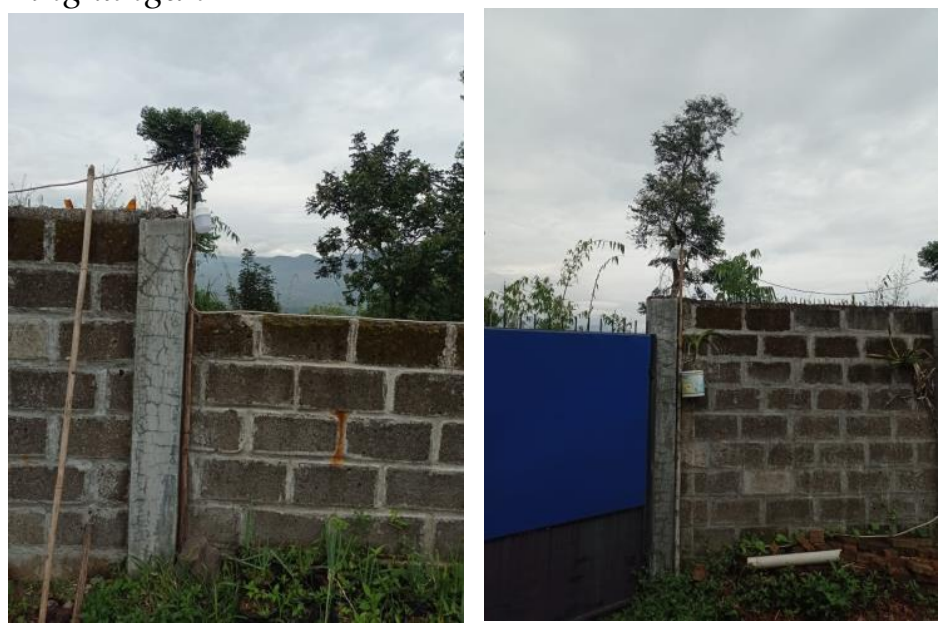
Berdasarkan Gambar 2 s/d Gambar 4, nampak bahwa banyak tempat yang harus diberikan pencahayaan. Selain di lokasi kandangnya, juga lampu dipasang di lingkungan sekitarnya dan juga untuk pencahayaan jalan. Berhubungan dengan ini, maka karyawan di peternakan ini harus selalu tepat waktu dan rajin dalam menghidupkan dan mematikan lampu. Hal ini ada hubungannya dengan penghematan energi yaitu lamanya waktu lampu dinyalakan, yang akan mempengaruhi besarnya penggunaan daya. Diperlukan juga kesadaran atau perilaku hemat energi dari karyawan tersebut. Menurut (Calvinus \& Setyaningsih, 2020), dalam penelitiannya yang dilakukan di sekolah, disebutkan bahwa umumnya yang dilakukan oleh siswa adalah lupa mematikan lampu yang menyala di dalam ruangan kelas. Hal ini bukanlah menjadi suatu kesalahan dari siswa yang belajar di sekolah namun budaya hemat energi belum terbiasa dalam diri siswa di sekolah. Perilaku hemat energi juga dapat dibantu dengan peran teknologi di jaman sekarang yaitu dengan memanfaatkan teknologi sistem otomatisasi. Saran yang bisa diberikan kepada pemilik peternakan adalah sebaiknya lampu yang berada di lingkungan atau di jalan diberikan sensor waktu (timer), sehingga lampu akan otomatis nyala dan mati. Namun hal ini memang diperlukan biaya tambahan pada awal penyediaan alatnya.

Berdasarkan survei dan wawancara dengan pihak mitra, beberapa permasalahan mitra adalah sebagai berikut:

1. Pihak mitra kurang paham dalam pemilihan lampu LED dan penempatan lampu untuk bagian ruang luar/lingkungan sekitar

2. Pencahayaan menggunakan lampu LED, namun dengan spesifikasi yang kurang mendetail

3. Daya perlampu masih tinggi, yaitu 28 watt/lampu, namun iluminansinya kurang optimal untuk luas kandang sekitar $120 \mathrm{~m}^{2}$, yang menggunakan 3 buah lampu

4. Pemilihan model/bentuk lampu yang kurang tepat untuk pencahayaaan sekitar kandang (outdoor) dan untuk penerangan jalan.

Solusi untuk pihak mitra yang kurang paham dalam pemilihan lampu LED dan penempatan lampu untuk bagian ruang luar/lingkungan sekitar, yaitu dengan memberikan pemahaman melalui pembekalan secara daring dan memberikan contoh-contoh lampu yang sesuai dengan penggunaan. Selain itu disampaikan tentang bagaimana penempatan lampu atau rumah lampu yang sesuai dengan lokasinya, dan pemilihan lampu yang hemat energi. Lampu hemat energi, ditunjukkan dengan nilai efikasi dalam satuan lumen/watt dari lampu tersebut. Berdasarkan pengujian yang dilakukan oleh (Palaloi et al., 2018), bahwa lampu TL-LED yang beredar dipasaran saat ini sudah ada yang mempunyai efikasi sebesar 130 lumen/watt. Palaloi (2018) melakukan pengujian terhadap 15 lampu TL-LED dari berbagai merk lampu, dengan daya 8 watt sampai dengan 18 Watt. Berdasarkan analisis efikasi lampu menunjukkan hasil bahwa efikasi tertinggi pada sampel tersebut sebesar $132 \mathrm{~lm} /$ Watt, sedangkan efikasi terendahnya sebesar $64 \mathrm{~lm} / \mathrm{Watt}$. Lampu Tipe A, Tipe D dan Tipe E memiliki efikasi yang tinggi yaitu di atas $120 \mathrm{~lm} /$ Watt, sedangkan lampu Tipe B, Tipe C dan Tipe F memiliki efikasi di bawah 100 lm/Watt.

Pihak mitra telah menggunakan lampu LED, yang dibeli dari toko elektronik di sekitar lokasi kandang sapi. Namun karena pengetahuan yang kurang memadai terhadap karakter lampu LED, maka pilihan lampu LED kurang tepat. Untuk itu solusinya adalah dilakukan penggantian terhadap lampu LED tersebut dengan spesifikasi yang tepat. Daya lampu yang digunakan di area kandang sapi adalah lampu LED 28 watt, namun iluminansinya kurang optimal untuk luas kandang sekitar $120 \mathrm{~m} 2$, yang menggunakan 3 buah lampu. Untuk itu solusinya adalah mengganti lampu LED yang tepat dengan efikasi yang tinggi. Diharapkan akan memberikan pencahayaan yang optimal. Pemilihan model/bentuk lampu yang kurang tepat untuk pencahayaaan sekitar kandang (outdoor) 
dan untuk penerangan jalan. Solusinya adalah mengganti model/bentuk lampu yang sesuai untuk pencahayaaan sekitar kandang dan penerangan jalan.

\section{METODE PELAKSANAAN PKM}

Tahapan solusi untuk pemahaman pemilihan lampu LED dan penempatan lampu.

- Pertama melakukan diskusi dengan pihak mitra tentang permasalahannya

- Melakukan survei secara online, dan meminta mitra untuk membantu mengirimkan fotofoto pencahayaan di lokasi dan penempatan lampu.

- Melakukan pembekalan tentang lampu hemat energi, jenis lampu LED, dan contohcontohnya secara online

- Memberikan pembekalan tentang cara menempatkan lampu sesuai peruntukannya.

Tahapan solusi untuk penggantian dan pemasangan lampu LED

- Melakukan analisis terhadap lampu LED dan rumah lampu yang digunakan, untuk menentukan penggantian lampu LED dan rumah lampu.

- Melakukan pembelian lampu LED dan rumah lampu melalui toko online dan mengirimkannya langsung ke pihak mitra.

- Melakukan rencana pemasangan lampu dan rumah lampu

- Melakukan pemasangan lampu, dengan meminta pihak mitra menyediakan teknisi, dan tim PKM memantaunya secara online

- Mengecek dan memastikan pemasangan lampu dan rumah lampu secara online menggunakan video call.

- Meminta pihak mitra untuk mengirimkan foto-foto dan video hasil pelaksanaan PKM

Tahapan untuk mengajak partisipasi mitra dalam kegiatan PKM

- Kesediaannya untuk melakukan wawancara/diskusi secara online untuk menjelaskan permasalahan yang dihadapi.

- Menyampaikan kondisi pencahayaan di peternakan sapi melalui video dan menjelaskannya

- Memberikan foto-foto dan video yang diperlukan oleh pelaksana PKM, saat survei

- Bersedia membantu pembelian barang perlengkapan kecil untuk pemasangan lampu.

- Menyediakan teknisi untuk pemasangan lampu.

- Bersedia mengirimkan foto-foto dan video hasil kegiatan PKM.

\section{HASIL DAN PEMBAHASAN}

Pencahayaan kandang sapi bagian penggemukan dan Pembibitan, serta tempat pembuatan pakan sapi.

Pencahayaan pada kandang sapi sebelumnya menggunakan lampu LED bentuk bohlam dengan daya 28 watt. Penggunaan lampu LED bentuk bohlam untuk area kandang seperti pada Gambar 2 kurang tepat, karena penyebaran cahaya dari lampu berbentuk bohlam, kurang menyebar, yaitu dengan sudut beam yang sempit. Kandang ini mempunyai ukuran $(17$ x 7,5 x 2,75) m, namun area yang diberikan pencahayaan cukup untuk bagian meletakkan makanan sapi, yaitu dengan area (17 $\mathrm{x} 2,5 \mathrm{x}$ 2,75). Supaya penyebaran cahaya menjadi lebih luas, maka lampu LED bentuk bohlam diganti dengan lampu LED berbentuk tabung (TL LED), dengan panjang 1,2 $\mathrm{m}$ (lihat Tabel 1). Daya lampu TL LED ini adalah 16 watt, dan arus cahaya sebesar 1600 lumen, jadi efikasi lampu ini adalah 100 lumen/watt. Digunakan temperatur warna 6500K. Lampu TL LED ini dipasang tanpa menggunakan kap lampu, supaya cahaya sebagian masih bisa menyebar ke arah atas. Gambar 5 menunjukkan pencahayaan malam hari untuk kandang pembibitan, yang tampak masih belum terisi sapi. Kandang ini merupakan bagian pengembangan yang ada di Peternakan Sawalaksa Buana. 


\section{Gambar 5}

Pencahayaan Kandang Pembibitan Malam Hari

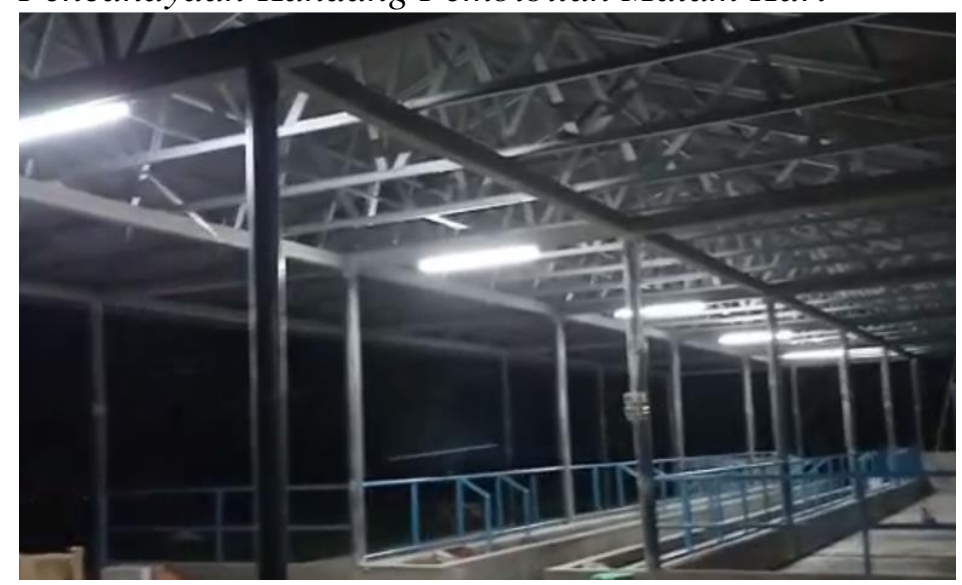

Pencahayaan pada bagian gudang/tempat pembuatan pakan sapi, sebelumnya juga menggunakan lampu LED berbentuk bohlam. Selanjutnya juga diganti dengan lampu TL LED, dengan spesifikasi yang sama dengan lampu untuk bagian kandang (lihat Tabel 1). Kandang kedua, saat ini telah selesai dibangun, ukuran $(25 \times 10 \times 3) \mathrm{m}$, dimanfaatkan sebagai kandang sapi betina untuk pembibitan, akan diisi sekitar 20 sapi betina. Pencahayaan kandang pembibitan juga menggunakan lampu TL LED, dengan jumlah lampu terpasang adalah 5 buah.

\section{Pencahayaan lingkungan peternakan sapi dan bagian saung.}

Lampu yang digunakan untuk pencahayaan lingkungan peternakan sapi dan bagian saung, juga menggunakan lampu LED tipe bohlam. Namun pemasangan lampu ini tanpa menggunakan kap lampu, hanya menggunakan tudung ala kadarnya. Hal ini kurang baik karena tudung seperti yang nampak pada gambar tersebut tidak bisa melindungi siraman air hujan, yang dikuatirkan akan menimbulkan korsleting listrik. Korsleting dalam KBBI, disebutkan sebagai terputusnya arus listrik karena kawat yang bermuatan arus positif dan negatif bersentuhan sehingga terjadi hubungan pendek. Hubungan pendek ini bisa menyebabkan percikan api, dan ini bisa membahayakan.

Lampu lingkungan ini tidak diganti, supaya masih bisa memanfaatkan lampu sebelumnya, meskipun lampu LED dengan daya 28 watt ini tidak diketahui nilai efikasinya (tidak tertera dengan jelas di boks lampu). Namun sudah dipesankan kepada pemilik peternakan, jika lampu ini sudah mati, maka pada saat akan memilih lampu LED, perlu untuk melihat spesifikasi yang ada didalam boksnya, dan memilih lampu LED dengan efikasi yang tinggi, yaitu >100 lumen/watt, seperti yang disebutkan oleh (Palaloi et al., 2018). Pada saat pelaksanaan kegiatan PKM, lampu lingkungan dan saung yang tanpa kap ditambahkan kap lampu, seperti terlihat pada Gambar 8 dan Gambar 9. Sementara Gambar 10 adalah pencahayaan saung dan lingkungan sekitar pada malam hari.

\section{Pencahayaan untuk sekitar jalan lingkungan.}

Pencahayaan didepan pintu gerbang peternakan Sawalaksa Buana, selain berfungsi sebagai pencahayaan pintu gerbang, juga sebagai pencahayaan sekitar jalan lingkungan. Lampu yang digunakan sebelumnya yaitu lampu LED tipe bohlam, dan juga tanpa adanya kap lampu. Untuk itu lampu LED ini juga perlu diberikan kap lampu atau lebih tepatnya sebagai rumah lampu. Istilah rumah lampu disebut juga sebagai luminer, yaitu satu kesatuan antara lampu, rumah lampu, komponen listrik, dan mekaniknya. Luminer lampu yang disesuaikan dengan kegunaannya dipeternakan ini seperti pada Gambar 2 bagian kiri. Tampak dari gambar lampu yang digunakan 
adalah lampu fluorescent PL, namun lampu PL ini akan diganti menggunakan lampu LED 28 watt, yaitu lampu yang digunakan sebelumnya. Sekali lagi supaya lampu lama masih bisa digunakan, namun pada saat mati nanti harus diganti dengan pilihan lampu LED yang berkualitas dan hemat energi.

\section{Tabel 1}

Penggunaan Tipe Lampu LED, Rumah Lampu dan Pencahayaan pada Area Kandang Sapi dan Sekitarnya

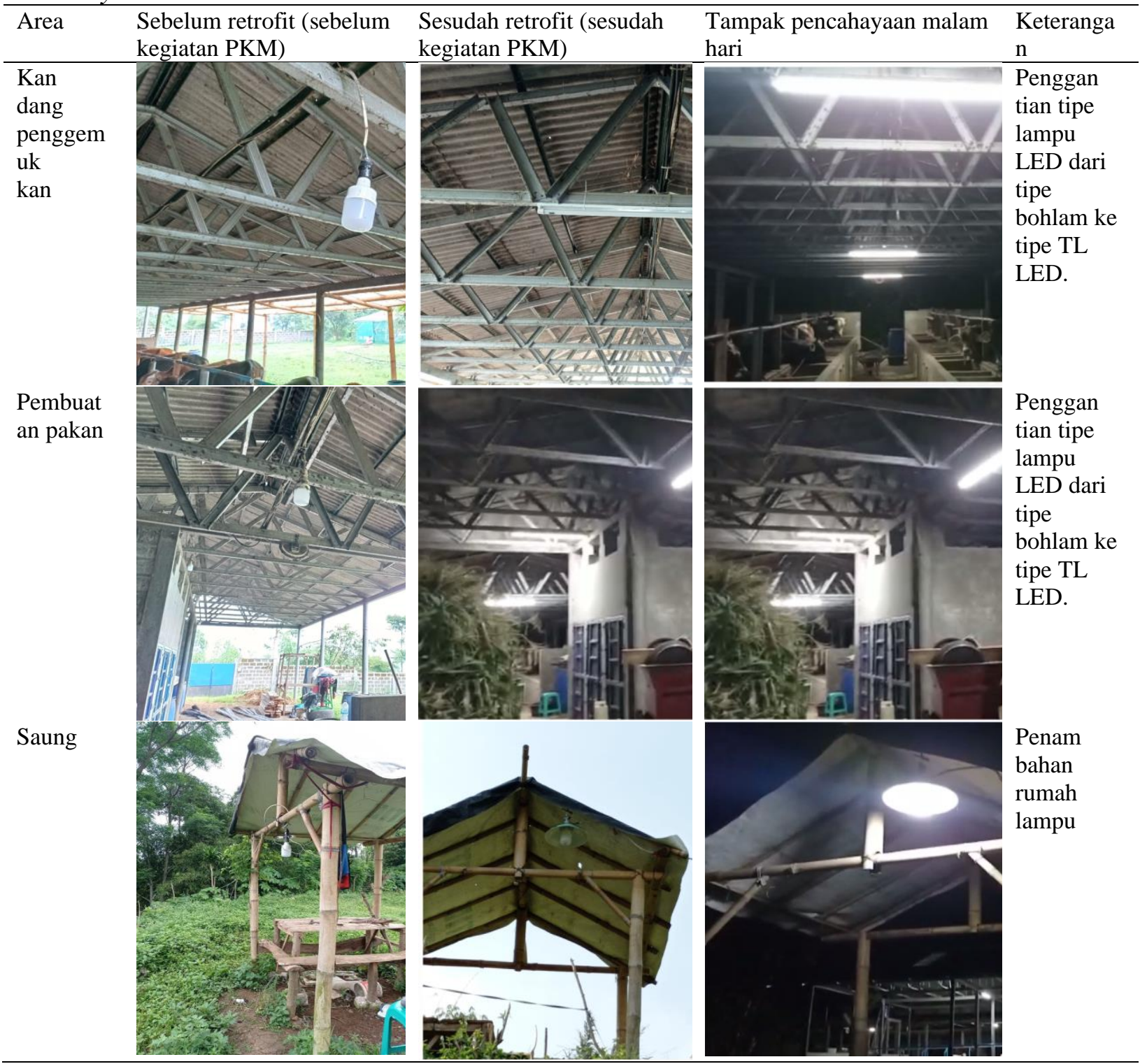




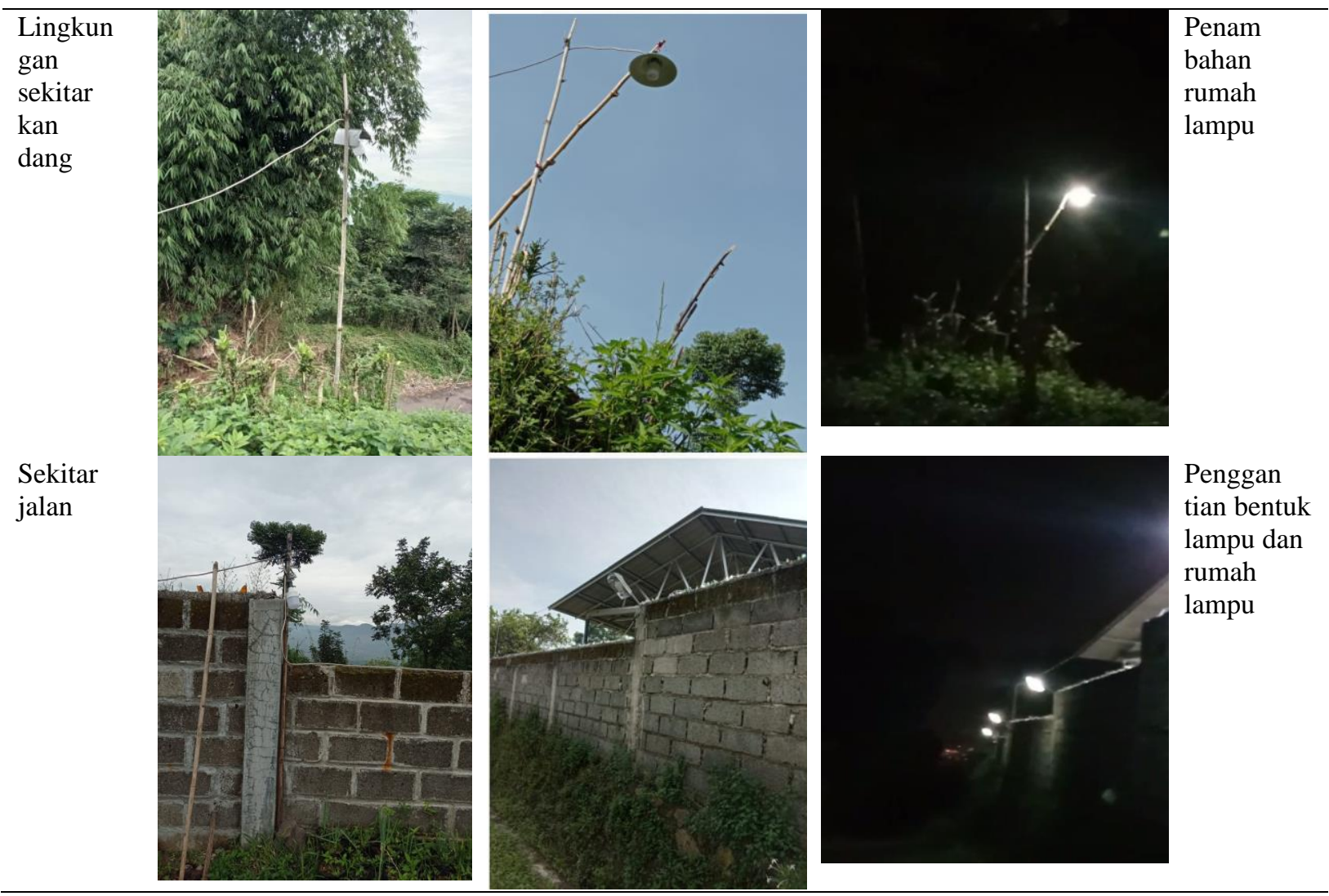

Luminer LED untuk penerangan jalan umum, baik untuk jalan lokal, jalan kolektor, dan jalan arteri berbeda dengan yang digunakan di peternakan ini, dengan ketinggian tiang antara $5 \mathrm{~s} / \mathrm{d} 9 \mathrm{~m}$, tergantung jenis jalannya. Suplei daya lampu berasal dari listrik PLN, dan daya lampu LED PJU antara 40 watt s/d 100 watt, dengan intensitas cahaya antara 15 s/d 20 lux (SNI 7391:2008). Jika intensitas cahaya melebihi nilai tersebut, maka akan dianggap boros energi, dan tidak memenuhi rekomendasi SNI (Setyaningsih, dkk, 2018). Hasil retrofit lampu dan bentuk rumah lampu untuk pencahayaan jalan lingkungan, seperti terlihat pada Tabel 1. Pencahayaan dari luminer ini cukup membantu pencahayaan bagi lalu lalang kendaraan bermotor malam hari atau pejalan kaki dan diharapkan mampu memberikan rasa aman.

\section{KESIMPULAN DAN SARAN}

Berdasarkan hasil kegiatan PKM di Peternakan Sawalaksa Buana, dapat diambil kesimpulan sebagai berikut:

1. Karyawan cukup paham menerima informasi tentang lampu LED yang berkualitas dan hemat energi, serta penggunaan rumah lampu.

2. Lampu LED yang digunakan di saung dan lingkungan di Peternakan Sawalaksa Buana, dimanfaatkan kembali, namun ditambahkan rumah lampu berbentuk bulat, sehingga menghindarkan lampu LED terkena air hujan secara langsung.

3. Lampu LED yang digunakan untuk pencahayaan jalan di Peternakan Sawalaksa Buana, dimanfaatkan kembali, namun ditambahkan rumah lampu yang sesuai kegunaannya, dan juga menghidarkan terkena air hujan.

4. Lampu LED 28 watt bentuk bohlam untuk pencahayaan kandang sapi, diganti dengan jenis lampu TL-LED 16 watt, sehingga pencahayaannya lebih merata dan efikasi lampu lebih tinggi, sehingga lebih hemat energi. Demikian juga pada area pembuatan pakan sapi dan gudang. 
Sebagai saran untuk kegiatan PKM selanjutnya dapat sekaligus melakukan desain pencahayaan untuk kandang sapi, sehingga dapat diketahui intensitas cahaya yang tepat untuk suatu peternakan, meskipun memang belum ada SNI nya.

Ucapan Terima Kasih (Acknowledgement)

Disampaikan terimakasih kepada Lembaga Penelitian dan Pengabdian kepada Masyarakat (LPPM) Universitas Tarumanagara, yang telah memberikan pendanaan untuk kegiatan ini. Terimakasih juga untuk mitra yaitu Peternakan Sapi Sawalaksa Buana, sehingga kegiatan PKM ini dapat dilaksanakan.

\section{REFERENSI}

Calvinus, Y. \& Setyaningsih, E. (2020). Perilaku hemat energi melalui penerapan teknologi smart school di SMAN 23 Tomang. Prosiding dari Seri Seminar Nasional Universitas Tarumanagara (SERINA UNTAR 2020).

Candra, H., Setyaningsih, E. \& Tji Beng, J. (April 2018). Analisis efisiensi komsumsi daya listrik dan biaya operasional lampu TL-LED terhadap lampu TL-T8. Jurnal Muara Sains, Teknologi, Kedokteran, dan Ilmu Kesehatan, 2(1), 186-193.

Pranamyaditia, C. D. (2016). Risiko keselamatan dan kesehatan kerja pada pekerja peternakan sapi di PT X Cabang Kota Kediri. The Indonesian Journal of Occupational Safety and Health, 5(1), 1-10.

Palaloi, S., Nurdiana, E., \& Wibowo, A. (Maret 2020). Pengujian dan analisis kinerja lampu TL LED untuk pencahyaan umum. Jurnal Standardisasi, 20(1), 75-82.

SNI 6197:2020. (2020). Konservasi energi pada sistem pencahayaan. Badan Standar Nasional.

SNI 7391:2008. (2008). Spesifikasi penerangan jalan di kawasan perkotaan, Badan Stadardisasi Nasional.

Setyaningsih, E., Zureidar, I. \& Soesaty, B. (April 2018). Evaluasi tata pencahayaan jalan secara kualitatif dan kuantitatif pada Jalan Pangeran Antasari, Jakarta. Prosiding dari Seminar Nasional Mesin dan Industri (SNMI XII) 2018, Riset Multidisiplin untuk Menunjang Pengembangan Industri Nasional, Bukittinggi.

Zuroida, R. \& Azizah, R. (Oktober 2018). Sanitasi kandang dan keluhan kesehatan pada peternak sapi perah di Desa Murukan Kabupaten Jombang. Jurnal Kesehatan Lingkungan, 10(4), 434-440 